UDC 94(47).084.6«1940»

Submitted: 21.06 .2016

LBC 63.3(0)6

Accepted: 20.10 .2016

\title{
ELECTIONS TO THE HIGHEST STATE AUTHORITIES IN WESTERN BELARUS IN 1940 AS AN ELEMENT OF THE REGION'SOVIETIZATION
}

\author{
Aleksandr V. Kuryanovich \\ Institute of Political Research "Political Sphere", Vilnius, Republic of Lithuania
}

\begin{abstract}
The article deals with one of the poorly studied fragments of Russian history - elections of deputies of the USSR Supreme Council and the BSSR Supreme Council for Western Belarus. Inclusion of this territory into the USSR and the BSSR in 1939 was the critical issue in the region in order to establish a social system that existed in the USSR and the Byelorussian SSR for over twenty years. Within a few months the Soviet government implemented a major event (the nationalization of industry, confiscation of the land fund, etc.), laid the foundation for a new system and launched the building of socialism in all directions. The study is considered an important element of the policy of the Soviet power - the election of the Supreme Soviet of the USSR and the BSSR Supreme Council of Western Belarus, which took place in 1940. On the basis of a wide range of original archival sources, most of which are introduced into scientific circulation for the first time, the author reveals a large-scale picture of the election campaign designed to persuade the millions of people who had lived for more than 15 years in a completely non-Bolshevik political and socio-economic conditions, the advantages of a fundamentally different social model on socialist principles, as well as significantly enhance the legitimacy of the Soviet regime.

The author assesses the situation prevailing in Western Belarus on the eve of the election, analyzes the electoral law, elections organizational aspects, forms and methods of campaigning. The special attention is paid to the unequivocal attitude of the people to the election campaign, and the appropriate assessment of the official results is carried out.

Key words: The Supreme Council, election campaign, candidates, agitation, deputy, electoral list, newsletter.
\end{abstract}

УДК 94(47).084.6«1940»

Дата поступления статьи: 21.06.2016

ББК 63.3(0)6

Дата принятия статьи: 20.10.2016

\section{ВЫБОРЫ В ВЫСШИЕ ОРГАНЫ ГОСУДАРСТВЕННОЙ ВЛАСТИ В ЗАПАДНОЙ БЕЛОРУССИИ В 1940 ГОДУ КАК ЭЛЕМЕНТ СОВЕТИЗАЦИИ РЕГИОНА}

\section{Александр Викторович Курьянович}

Институт политических исследований «Политическая сфера», г. Вильнюс, Литовская Республика

Аннотация. В исследовании рассматривается одна из малоизученных страниц отечественной истории выборы депутатов Верховного Совета СССР и Верховного Совета БССР от Западной Белоруссии, состоявшиеся через несколько месяцев после включения этой территории в состав Союза ССР и Белорусской ССР. На основе широкого комплекса оригинальных архивных источников, большинство из которых вводится в научный оборот впервые, раскрывается широкомасштабная картина избирательной кампании, призванной убедить многомил- лионное население, жившее свыше полутора десятка лет в совершенно отличных от большевизма политических и социально-экономических условиях, в преимуществе принципиально иной общественной модели на социалистических началах, а также существенно повысить легитимность советской власти.

В работе оценивается обстановка, сложившаяся в Западной Белоруссии накануне выборов, анализируется избирательное законодательство, организационные моменты выборов, формы и методы предвыборной агитации, уделяется внимание далеко не однозначному отношению к избирательной кампании жителей региона, дается соответствующая оценка официальным итогам.

Ключевые слова: Верховный Совет, избирательная кампания, кандидаты, агитация, депутат, избирательный список, бюллетень. 
Несмотря на обилие научной литературы по Западной Белоруссии в целом, избирательная кампания в ней в 1940 г. практически не освещена в трудах специалистов как в Республике Беларусь, так и в странах СНГ. Большинство авторов при изучении в этом регионе большевистской политики, называемой советизацией, отдают приоритет ее хозяйственным преобразованиям (национализации и коллективизации) [1], образованию [28], культуре [26], борьбе с антисоветским подпольем, репрессиям в отношении «осадников» и польских военных [22], судебной системе [23], кадрам [24], архивным учреждениям [2].

Такое незаслуженное игнорирование выборов берет свое начало со времен советской историографии, где имела место лишь победоносная констатация итогов выборов, а правомерность подобных электоральных кампаний считалась неприкосновенной и не подлежащей никакому сомнению [3;25].

Основательные работы по данной тематике отсутствуют в современной польской историографии, представители которой традиционно уделяют внимание бывшим «кресам всходним». В настоящее время имеется практически единственная монография, где выборы 1940 г. в Западной Белоруссии рассматриваются на примере лишь одной области - Белостокской [29].

Накануне выборов ситуация для руководства Белорусской ССР была двоякой. С одной стороны, оно прекрасно понимало риски, связанные с будущей кампанией и помнило опыт выборов в Народное собрание Западной Белоруссии 22 октября 1939 г., столкнувшись с многочисленными фактами проявления настоящего антисоветизма, случаев срыва выборов. С другой стороны, в ходе этих выборов власти в определенной степени вникли в ситуацию в регионе, изучили настроение населения. Кроме того, имелся положительный опыт в проведении выборов в Верховный Совет СССР в 1937 г. и в БССР в 1938 году.

Обстановка в Западной Белоруссии осложнялась рядом обстоятельств. Из них можно выделить, по крайней мере, два существенных момента.

Первая проблема состояла в плачевном положении экономики, обременненной безработицей и беженцами, катастрофически пада- ющим жизненным уровнем подавляющего большинства населения, для которого проблемой номер один стал дефицит - острая нехватка товаров первой необходимости. Так, на специальном совещании ЦК КП(б)Б по вопросам Западной Белоруссии 8 января 1940 г. констатировалось, что «в городе нет зубной щетки, иголки, шнурков, мази для обуви, одеколона» [13, л. 15]. По этой причине настоящим бедствием региона стала спекуляция. 2 февраля 1940 г. нарком торговли Белорусской ССР В.Г. Ванеев, находясь в Белостоке, в письме на имя первого секретаря ЦК КП(б)Б П.К. Пономаренко просил рассмотреть вопрос о применении высшей меры наказания в отношении «особо злостных спекулянтов» [19, л. 69].

Руководство БССР приняло беспрецедентные меры для насыщения рынка западных областей республики промышленными и продовольственными товарами. Специальное совещание ЦК КП(б)Б по организационным и хозяйственно-политическим вопросам Западной Белоруссии 9 марта 1940 г. утвердило решение об оперативной отгрузке в регион к двадцатому числу того же месяца 18 тыс. т соли, 2 тыс. т сахара, 830 т кондитерских изделий. Среди товаров также значились хлопчатобумажные ткани, мыло, спички, нитки и папиросы «из Керчи и Феодосии» [15, л. 3].

На вышеупомянутом совещании обсуждались вопросы нехватки вагонов, слабая железнодорожная и шоссейная инфраструктура Западной Белоруссии. Это ставило под угрозу своевременную доставку товаров и могло повлиять на выборы. Недаром 29 января 1940 г. Белостокский обком направил в ЦК КП(Б) докладную записку, в которой слезно просил: все, что есть, «послать побыстрее в Белосток и только самолетом, так как железная дорога не обеспечивает быстрой доставки» [5, л. 58].

Вторая проблема касалась наличия «польского элемента» в регионе. При этом особое внимание советская администрация обращала на «осадников», военных, лесников, сторожей, то есть на тех, кто был потенциальным владельцем оружия и мог повернуть его против новой власти. Для выхода из ситуации большевики прибегли к крайнему методу, который с успехом в масштабах СССР будет применяться позднее, - выселению. 
Техническую сторону будущей депортации 7 января 1940 г. обрисовал нарком внутренних дел БССР Л.Ф. Цанава на специальном совещании у первого секретаря ЦК КП(б)Б П.К. Пономаренко о работе в Западной Белоруссии. По словам главы НКВД, выселение планировалось в один день с привлечением большого количества населения, лояльного к советской власти. Пять западных областей разбивались на 37 оперативных участков, что, по заверению Л.Ф. Цанавы, позволит «закончить операцию одним коротким ударом» [14, л. 9].

21 февраля 1940 г. П.К. Пономаренко в докладной записке на имя И.В. Сталина, а также секретарей ЦК ВКП(б) А.А. Андреева и Г.М. Маленкова сообщал, что 10 февраля в Западной Белоруссии при участии 15 тыс. местных жителей были осуществлены мероприятия, в ходе которых выселили 9775 «польских» семей общей численностью 50732 чел. [16, л. 76].

Наряду с подобными варварскими акциями в целях достижения максимально благоприятных итогов выборов руководство БССР решило сыграть на трудовом энтузиазме жителей региона и одновременно смягчить проблему безработицы. На официальном уровне было объявлено о форсированной реконструкции Днепро-Бугской водной системы. В докладной записке Организационно-инструкторского отдела ЦК КП(б)Б от 27 февраля 1940 г. имеются данные о том, что в данной строительной акции были задействованы 3 тыс. чел. [12, л. 2].

Сами выборы в Верховный Совет БССР и Верховный Совет СССР были назначены на 24 марта 1940 г. специальными указами Президиума Верховного Совета БССР и Президиума Верховного Совета СССР от 21 января 1940 г. соответственно.

Если говорить о численности депутатов, то в Верховный Совет БССР планировалось делегировать 202 народных избранника: в соответствии с Конституцией БССР 1937 г. Верховный Совет формировался по формуле «один депутат на 20000 населения». При этом наибольшее - 58 - количество кандидатов регистрировалось от Белостокской области, а наименьшее - 21 - от Пинской. Барановичская, Вилейская и Брестская области выдвигали 51, 40 и 32 претендента соответственно.
Избирательную кампанию в Верховный Совет СССР регулировало специальное Положение от 9 июля 1937 г., а в Верховный Совет БССР - практически идентичное, списанное с общесоюзного, Положение от 27 февраля 1938 года. Несмотря на ряд норм (например, выдвижение кандидатов осуществлялось исключительно компартией, профсоюзами, иными зарегистрированными организациями, а также трудовыми коллективами колхозов, совхозов и воинскими частями), которые нивелировали идею выборов, положения по некоторым моментам внешне выглядели довольно демократично. Они ликвидировали ранее имевшие место классовые, социальные, религиозные и другие препятствия для свободного волеизъявления граждан, предусматривали второй тур, вводили уголовную ответственность - лишение свободы на срок до 3 лет - за фальсификацию («заведомо неправильный подсчет голосов») итогов выборов [20].

Усилиями пропагандистов и агитаторов был разработан примерный план по изучению этих положений. На протяжении семи уроков граждане должны были изучить общественное устройство СССР и БССР, Верховный Совет СССР и БССР, порядок выдвижения кандидатов, образование избирательных округов, принцип формирования избирательных комиссий, порядок голосования, подведение итогов выборов.

При изучении положений, как свидетельствуют архивные источники, в частности, материалы по выборам в Верховный Совет СССР и в Верховный Совет БССР (январьдекабрь 1940 г.), в обязательном порядке необходимо было затронуть и такие вопросы: воссоединение великого белорусского народа в едином белорусском государстве - блестящая победа ленинско-сталинской политики; бывшая панская Польша была тюрьмой народов; десятки тысяч безработных получили работу; СССР - страна самого крупного в мире социалистического сельского хозяйства и т. д. [10, л. 88$]$.

В целях идеологической обработки населения и аргументации правомерности внешнеполитического курса СССР в уроки включались темы, касающиеся заключения пакта Молотова-Риббентропа, советско-германско- 
го договора о дружбе и границе, советскояпонских военных конфликтов у оз. Хасан и p. Халхин-Гол, советско-финляндской войны.

Однако свидетельством того, что Конституция и данные положения являлись в условиях сталинского общественно-политического режима лишь фикцией и декорацией, пародией на демократию, стало секретное постановление ЦК КП(б)Б от 5 февраля 1940 г. № П-125 «О выборах в Западной Белоруссии» с резолюциями П.К. Пономаренко, Л.Ф. Цанавы и председателя СНК БССР К.В. Киселева. Под грифом «опубликование запрещается» этот документ был разослан обкомам, горкомам и райкомам КП(б)Б Барановичской, Белостокской, Брестской, Вилейской и Пинской областей.

При анализе постановления можно прийти к выводу о том, что приближающаяся кампания рассматривалась республиканским руководством явно не в качестве демократического мероприятия с добровольным участием. Планировалась своего рода силовая спецоперация, где не должно было быть никаких сбоев: «Партийные организации должны учесть, что выборы в Верховный Совет СССР и БССР будут значительно сложнее, чем выборы в Народное собрание: буржуазно-националистические агенты приложат все силы, чтобы помешать выборам, “протащить" своих людей в депутаты» [8, л. 33].

Постановление содержало предельно короткие подготовительные сроки. Списки избирательных участков должны были быть составлены не позднее 8 февраля. К этому же числу требовалось сформировать окружные и участковые избирательные комиссии в составе председателя, заместителя, секретаря и 4-8 членов, из которых 25-30\% - женщины. Не позднее 20 февраля 1940 г. ЦК КП(б)Б должен был получить сведения об общем количестве избирателей по областям.

Постановление затрагивало и иные организационные моменты, а также идеологические нюансы. Это и создание кружков по изучению Конституции СССР и БССР, и четкая фиксация предприятий, учреждений и организаций, выдвигающих кандидатов, и обеспечение «поголовной явки избирателей», и создание блока беспартийных и коммунистов, и «четкое разьяснение принципов ленинско-сталинской национальной политики».
Отдельным пунктом постановление предусматривало порядок выдвижения кандидатов в сельской местности. В преддверии выборов советская власть не решилась на сплошную коллективизацию в регионе, опасаясь массовых крестьянских выступлений. Так, 7 января 1940 г. на специальном совещании о работе в Западной Белоруссии П.К. Пономаренко категорически заявил, что «образование колхозов тут нельзя принять как систему» $[14$, л. 78]. Руководитель БССР считал целесообразным на данном этапе создание в каждой западной области республики от трех до пяти совхозов. Поэтому постановление констатировало: «Ввиду отсутствия колхозов в Западной Белоруссии установить, что выдвижение кандидатов в сельской местности осуществляется общими собраниями крестьян по сельским советам» $[8$, л. 13].

В постановлении прослеживались некоторые политехнологические моменты, которые стали определенным новшеством в избирательной кампании. Например, агитаторам не рекомендовалось сводить пропагандистскую работу к обещаниям материального изобилия. В обязательном порядке они должны были разъяснять, что основой благополучия является труд [8, л. 6]. Помимо этого, идеологи обязывались говорить не только об успехах советской власти, но и указывать на отдельные недостатки («местные вопросы»).

Постановление грубо нарушало нормы избирательного законодательства, утвержденного в рамках самой советской системы. Например, вопреки ст. 71 вышеотмеченных положений, оно отменяло конверты, в которые вкладывались бюллетени для голосования. Пункт «б» ст. 80 положений признавал недействительными бюллетени, «поданные без конверта или в конверте неустановленного образца». Вместо конвертов для различия бюллетеней вводились разные цвета: белый - Coвет Союза, светло-голубой - Совет Национальностей и светло-зеленый - Верховный Совет БССР. Польские исследователи - и не без оснований - полагают, что отказ от конвертов ставил целью предотвратить порчу бюллетеней и отслеживание надписей антисоветского характера [29, s. 222].

Что касается Верховного Совета СССР, то, учитывая двухуровневую конструкцию дан- 
ного органа, необходимо было избрать депутатов в Совет Союза и Совет Национальностей. В первую палату планировалось направить 16 кандидатов (в соответствии с Конституцией СССР 1936 г. 1 депутат избирался от 300 тыс. чел.), из них 5 приходилось на Белостокскую область, 4 - на Барановичскую, 3 на Вилейскую, 2 - на Брестскую и Пинскую области.

А вот при определении количества посланцев от БССР в Совет Национальностей, власти руководствовались не буквой закона, а логикой. Дело в том, что 12 декабря 1937 г. прошли выборы в Верховный Совет СССР. От Белорусской ССР туда попали 44 избранника: 19 - в Совет Союза и 25 (по конституционной норме) - в Совет Национальностей. И если вопрос представительства в Совете Союза решался в силу относительности количества депутатов этой палаты в зависимости от населения, то проблема в отношении Совета Национальностей была непреодолимой по причине закрепления в Конституции точного числа представителей (25 чел.) в этой палате от каждой союзной республики. Естественно, делегировать в Совет Национальностей 25 чел. от БССР считалось невозможным, поэтому власти приняли решение об избрании от западных областей республики шестерых депутатов. Белостокская область, учитывая, что она являлась большей по территории и количеству населения, делегировала двоих депутатов, остальные области - по одному.

Довольно сложно выглядела организационная схема по выборам в Верховный Совет СССР и БССР 24 марта 1940 г. Низшим звеном являлись 4100 участковых избирательных комиссий. Далее шли окружные избирательные комиссии: 22 - по выборам в Верховный Совет СССР и 202 - в Верховный Совет БССР. Конструкцию замыкали Центральная избирательная комиссия по выборам в Верховный Совет БССР и отдельная Республиканская комиссия по выборам в Совет Национальностей.

При формировании состава окружных и участковых избирательных комиссий советская власть нередко следовала общеизвестному правилу «разделяй и властвуй». Оно сводилось к тому, что членами избирательных комиссий становились не только кадровые боль- шевики или посланцы из восточных областей, но и жители Западной Белоруссии, обиженные поляками. Например, Каменецкий районный комитет КП(б)Б Брестской области докладывал в Минск о том, что членом окружной избирательной комиссии по выборам в Совет Национальностей стал И.У. Курьянович - педагог, который в период польского господства столкнулся с запретом на профессию [19, л. 63].

Подготовка к выборам 24 марта 1940 г., как и в прошлые избирательные кампании, не обходилась без ошибок и упущений со стороны властей. Значительное затруднение для администрации представляло составление списков избирателей. Нередко имели место ситуации, когда погрешности всплывали буквально за несколько дней до выборов. Так, 21 марта 1940 г. Л.Ф. Цанава в спецсводке НКВД информировал П.К. Пономаренко о том, что в Гродно в списке избирателей были искажены 50 фамилий, а в Белостоке - пропущена целая улица с населением в несколько сот человек [17, л. 55]. Прокурор Белорусской ССР И.Д. Ветров 22 марта 1940 г. в спецдонесении № 12 на имя П.К. Пономаренко отмечал, что в Домбровском районе Белостокской области в списки включены лица, не достигшие 18 лет, ряд фамилий печатался без имен и отчеств, однофамильцы обозначались черточками [6, л. 105].

Обстановка в регионе накануне выборов тщательно контролировалась НКВД. Любая внештатная ситуация (даже незначительное происшествие) поднималась на принципиальную высоту, становилась объектом пристального внимания спецслужб и, естественно, об этом докладывалось высшему руководству республики. 3 марта 1940 г. Л.Ф. Цанава в спецсводке НКВД ставил в известность П.К. Пономаренко о том, что органы «тщательно расследуют» инцидент, связанный с задымлением дымоходной трубы 29 февраля 1940 г. в г. Пружаны Брестской области в помещении школы - избирательного участка № 10 [17, л. 12].

Сами органы внутренних дел, следуя репрессивной логике, культивировали в регионе атмосферу подозрительности, недоверия, раскрывали мифических врагов. 14 марта 1940 г. Л.Ф. Цанава в спецсводке НКВД рапортовал П.К. Пономаренко о вскрытии на территории Гадутишского района Вилейской 
области контрреволюционного националистического подполья, куда входили члены бывших литовских организаций «Святой Казимир» и «Культура». Их цель, утверждал нарком, состояла в том, чтобы сорвать выборы в западных областях БССР [17, л. 176].

Выборы потребовали привлечения немалых затрат. Если на участковые избирательные комиссии по смете Президиума Верховного Совета БССР от 8 февраля 1940 г. было выделено 1947500 руб., то на окружные избирательные комиссии по выборам в Верховный Совет СССР - 220000 руб., в Верховный Совет БССР - 343000 руб. [4, л. 8]. Любопытен следующий факт: при почти десятикратном различии количества союзных и республиканских депутатов, сумма, выделенная на последних, лишь на 123000 руб. превышала ту, которая предназначалась на предвыборные расходы в две палаты. Это свидетельствовало о том, что для руководства БССР выборы в Совет Союза и Совет Национальностей были гораздо важнее с политической точки зрения, поэтому туда вкладывалось больше средств.

10 февраля 1940 г. из Государственного издательства при СНК БССР на имя секретаря ЦК КП(б)Б В.Н. Малина пришла «предварительная калькуляция на агитационномассовую литературу для избирательной кампании в западных областях БССР» 163930 руб. В этой сумме львиную долю составляли расходы на портреты кандидатов (43 050 руб.) и на агитационные цветные плакаты (51 600 руб.) [5, л. 20]. Остальные средства шли на издание положений о выборах в Верховный Совет СССР и БССР на русском и белорусском языках, а также Конституции СССР (на русском и белорусском языках) и Конституции БССР (на русском и белорусском языках). Если тиражи положений в зависимости от области колебались в пределах от 17000 до 30000 экз., то Конституций от 1000 до 4000 экз.

Из «предварительной калькуляции» видно, что издавались речи и выступления советских руководителей трехлетней и четырехлетней давности. Например, по состоянию на 3 февраля 1940 г. доклад И.В. Сталина о проекте Конституции на Чрезвычайном VIII Bceсоюзном съезде Советов 25 ноября 1936 г. поступил в Белостокскую, Барановичскую, Вилейскую, Пинскую и Брестскую области в количестве $3570,4400,1300,1275$ и 2 200 экз. соответственно. Почти в таком же объеме по областям были распределены тиражи издания предвыборной речи И.В. Сталина в Большом театре 11 декабря 1937 года [5, л. 63].

Планировался выпуск и других изданий, предназначенных специально для молодежи Западной Беларуси. 26 ноября 1939 г. ЦК КП(б)Б была утверждена соответствующая справка, в которой значились брошюры «О комсомоле» (И.В. Сталин), «Что советская власть дала трудящимся» (М.И. Калинин), произведения советского писателя Л.А. Кассиля, рассказы о Павлике Морозове [5, л. 55].

По причине материальных трудностей выход этих изданий задерживался. 11 декабря 1939 г. секретарь ЦК ВЛКСМ О.П. Мишакова обратилась с письмом к первому заместителю начальника Управления пропаганды и агитации ЦК ВКП(б) П.Н. Поспелову с просьбой посодействовать изданию вышеотмеченных книг «для молодежи новых областей Белоруссии» путем выделения 25 т обычной и 5 т обложечной бумаги $[4$, л. 6$]$.

Огромное количество бумаги планировалось расходовать на изготовление бюллетеней и другой документации. Согласно смете, утвержденной ЦК ВКП(б) 8 февраля 1940 г., Москва должна была выделить Белорусской ССР 509 стоп бумаги: 116 - на каждый вид бюллетеня и 161 - на списки избирателей, протоколы голосования и т. д. [4, л. 8].

Картину привлечения людских ресурсов раскрывает докладная записка В.Н. Малина на имя П.Н. Поспелова, которая была отослана 26 мая 1940 года. Из записки следует, что в предвыборной кампании приняли участие 46013 агитаторов: Белостокская область 17 000; Брестская - 7 500; Барановичская 6 391; Пинская - 8000 ; Вилейская - 7122 [10, л. 62]. При осуществлении своей деятельности агитаторы должны были следовать определенным указаниям: использовать, например, географическую карту, произведения Ч. Диккенса и М. Твена. Одно из требований сводилось к тому, чтобы агитаторы говорили «попростому», без использования иностранных терминов. В пример ставился В.И. Ленин, ко- 
торый призывал вместо термина «дефект» употреблять «недочет» [27, с. 33].

В основном деятельность агитаторов осуществлялась в традиционном формате предвыборные митинги и кружки.

Так, согласно докладной записке В.Н. Малина, в феврале 1940 г. в Вилейской области было проведено 1970 митингов с участием 218958 чел., из которых выступили 3233 избирателя. В Брестской области прошло 1128 митингов с участием 205652 чел. [10, л. 61].

29 февраля 1940 г. заведующий Организационно-инструкторским отделом ЦК КП(б)Б Г.Б. Эйдинов в докладной записке в ЦК ВКП(б) отмечал, что «по не полным данным» в пяти западных областях Белорусской ССР работают 9403 кружка, которыми охвачено 346175 чел. [16, л. 104].

В некоторых случаях агитаторы применяли креативные формы пропаганды, проявляли изобретательность. Например, в Барановичской области, как следует из той же докладной записки В.Н. Малина, в феврале 1940 г. специальная агитбригада осуществила лыжный пробег протяженностью 482 км, побывав при этом в 9 райцентрах и 48 местечках, сделав 50 докладов и проведя 28 бесед [10, л. 72].

На страницах средств массовой информации всячески популяризировались кандидаты «нерушимого» блока коммунистов и беспартийных. Как правило, формат такой популяризации представлял собой очерки, построенные по одному шаблону: сначала шла речь о тяжелой жизни, крайней бедности кандидата в дореволюционное время. Затем утверждалось, что только советская власть дала ему шанс выбиться в люди, стать счастливым человеком.

Фаворитом в этом отношении, пожалуй, стал кандидат в депутаты Совета Национальностей, известный деятель комсомола Западной Белоруссии С.О. Притыцкий. Газеты активно «пиарили» эпизод из жизни С.О. Притыцкого, связанный с покушением в январе 1936 г. на провокатора Я.Е. Стрельчука в суде г. Вильно [21, с. 3].

Другим известным людям также предстояло стать народными избранниками. Так, П.К. Пономаренко, К.В. Киселев и белорусский литератор Ф.С. Пестрак выдвигались в Совет Союза. Кандидатами в депутаты Вер- ховного Совета БССР стали Л.Ф. Цанава и народные поэты БССР Я. Купала (И.Д. Луцевич) и Я. Колас (К.М. Мицкевич).

15 марта 1940 г. последовало обращение ЦК КП(б)Б к избирателям в связи с предстоящей кампанией. По смыслу оно мало чем отличалось от предыдущих обращений накануне выборов в Верховный Совет СССР 1937 г. и Верховный Совет БССР 1938 года. Наряду с призывом голосовать за коммунистов и беспартийных в обращении, в частности, говорилось: «Народы Западной Белоруссии, живя под ярмом польских помещиков и капиталистов, всегда обращали свои взоры на Восток, на страну социализма, с надеждой ожидая дня, когда на их земле засияет яркое солнце Советов» $[18$, л. 4]. В обращении восхвалялась советская женщина. Царская Россия представлялась не иначе как тюрьма народов.

Текст обращения в обязательном порядке согласовывался с Москвой. Скорее всего, по инициативе центральных органов в обращении появился следующий панегирик: «Да здравствует наш родной отец, друг и учитель, наш вождь товарищ Сталин!» [7, л. 24]. Окончательный вариант обращения был отослан на имя Г.М. Маленкова утром 14 марта 1940 года.

Официальные итоги выборов дает отчет инструктора Организационно-инструкторского отдела ЦК КП(б)Б Г.М. Гершмана. Из общего количества избирателей (2930 628 чел.) участие приняли 2909450 чел. или 99,27\%. За кандидатов блока коммунистов и беспартийных проголосовали 2850406 чел. или 97,97 \% (см. таблицу).

При этом 11 районов добились стопроцентной явки избирателей: Лидский, Клецкий (Барановичская область), Видзовский, Диснянский (Вилейская область), Антопольский, Дивинский, Каменецкий, Коссовский, Пружанский, Шерешевский (Брестская область), Теханский (Пинская область). Наиболее низкая явка $(83,67$ \%) наблюдалась в Гадутишковском районе Вилейской области [9, л. 2].

Национальный состав депутатов Верховного Совета БССР от западных областей, согласно отчету Г.М. Гершмана, выглядел следующим образом: белорусы - 136, русские 33 , украинцы - 4, евреи - 12 , поляки - 15 , грузины - 1 , литовцы - 1 . Такая раскладка с преобладанием белорусов и наличием русских 
A.B. Курьянович. Выборы в высшие органы государственной власти в Западной Белоруссии

Результаты голосования по областям

\begin{tabular}{|l|c|c|c|}
\hline \multicolumn{1}{|c|}{ Область } & $\begin{array}{c}\text { Количество избирателей } \\
\text { (тыс. чел.) }\end{array}$ & $\begin{array}{c}\text { Приняло участие } \\
\text { в голосовании (тыс. чел.) }\end{array}$ & $\begin{array}{c}\text { Подано голосов } \\
\text { за кандидатов (тыс. чел.) }\end{array}$ \\
\hline Барановичская & 723407 & 720052 & 705729 \\
\hline Белостокская & 873166 & 862630 & 844378 \\
\hline Брестская & 477775 & 476457 & 470938 \\
\hline Вилейская & 574109 & 568486 & 549410 \\
\hline Пинская & 282171 & 281825 & 279951 \\
\hline
\end{tabular}

Примечание. Составлено и рассчитано по данным: [9, л. 2].

и украинцев на втором и третьем местах соответственно была заложена в ходе выборов в Верховный Совет БССР в 1938 году. Кроме того, депутатами стали 38 женщин, 84 члена компартии, 9 комсомольцев и 109 беспартийных [9, л. 20].

Оценивая итоги выборов, можно с уверенностью предположить, что многие избиратели региона искренне проголосовали за коммунистических и беспартийных выдвиженцев. В новой власти они видели альтернативу старым польским порядкам, лишивших их многих прав и возможностей, в том числе и свободы волеизъявления. Поэтому советские выборы, несмотря на их формальный характер, вызывали у жителей Западной Белоруссии чувство причастности к великим событиям, к созиданию новой жизни, о чем свидетельствуют надписи на избирательных бюллетенях, прославляющих И.В. Сталина, коммунизм.

В то же время выборы свидетельствовали о крайнем недовольстве советской властью определенной части населения и даже о ее неприятии. При этом недовольство выражалось чаще в пассивной форме: в архивных материалах имеются единичные свидетельства радикальных протестов. Докладная записка В.Н. Малина от 26 мая 1940 г., которая констатировала «активизацию контрреволюционных и клерикальных элементов в связи с подготовкой к выборам», приводит следующие факты. В Дрогичинском районе Пинской области на одном из избирательных участков разразился пожар, устроенный «подосланным» тринадцатилетним ребенком. Если, по данным В.Н. Малина, в ряде районов Витебской области «кулачество подкупало бедняков махоркой, чтобы они не шли голосовать», то на одном из избирательных участков Белостокской области дважды перерезалась телефоная линия [10, л. 84-85].
Самыми распространенными способами негативного отношения к выборам стали поговорки, частушки, а также порча бюллетеней и надписи, карикатуры, рисунки на них антисоветского характера.

Отдельный пласт антисоветских настроений устойчиво связан с социально-экономическими и бытовыми вопросами. 25 февраля 1940 г. корреспондент «Известий» писал П.К. Пономаренко о том, что в Вилейской области органами НКВД зафиксировано следующее высказывание: «Советской власти дождались, теперь в очереди давись» [10, л. 149]. Весьма популярной, отмечал корреспондент «Известий», особенно среди молодежи, стала частушка, родившаяся в д. Соловьи Поставского района этой же Вилейской области: «В колхоз дорога проста, а с колхоза - косяком, в колхоз - в ботах, а из колхоза - босяком» [12, л. 7].

Согласно докладной записке В.Н. Малина от 26 мая 1940 г. в г. Волковыске Белостокской области агитатору задали следующий вопрос: какое же в СССР равенство, если советский офицер получает 2000 руб., а рабочий - 300 руб. [10, л. 156].

Материалы по выборам в Верховный Совет СССР и в Верховный Совет БССР от западных областей республики (январь-декабрь 1940 г.) свидетельствуют о том, что антисоветские настроения имели и ярко выраженный политический оттенок, замешанный на крайней религиозности, с одной стороны, и культе Польши - с другой. Появлению соответствующих надписей на бюллетенях типа «Да здравствует Польша!», «С нами Бог!» в немалой степени способствовало проведение выборов в день католической Пасхи, что еще больше политизировало общество. В качестве своеобразного эталона таких настроений можно привести надпись на бюллетене в Соколовском районе Белостокской области: «Уничто- 
жили нашу дорогую мать-Польшу, душите ее своими грязными лапами, но мы, дети ее, бодрствуем и уже готовим ножи, чтобы разрезать оковы, ее стесняющие. Польша не умерла, а уснула, чтобы вспыхнуть огромной силой и пламенем зажечь и уничтожить ваш проклятый коммунизм. Христос, воскреси Польшу, как пробудил и воскресил умершего Лазаря» [11, л. 280].

Те жители региона, которые не принимали советскую власть, отождествляли ее с евреями. Это объясняет большое количество бюллетеней с надписями-призывами «бить жидов». Например, в Видзовском районе Вилейской области, согласно вышеотмеченным материалам по выборам, зафиксировано «послание» следующего характера: «Бей жидов, спасай Белоруссию, потому что Россия пропала» [11, л. 346]. В Браславском районе Вилейской области на бюллетене избиратель начертал: "Долой грузинско-жидовскую власть» [11, л. 358].

В таком контексте логично появление многочисленных надписей, содержащих оскорбления, похабные и матерные выражения в адрес высшего руководства СССР (И.В. Сталин, В.М. Молотов, К.Е. Ворошилов и др.). В Островецком районе Вилейской области в избирательной урне была обнаружена карикатура - отрубание головы И.В. Сталину [11, л. 347].

Руководство Белорусской ССР тоже не стало исключением. В Миорском районе Вилейкой области на бюллетене кандидата К.В. Киселева было написано слово «дурак» [11, л. 339].

И, напротив, имели место многочисленные надписи, славящие как польских государственных деятелей (Ю. Пилсудский, Э. РыдзСмиглы, И. Мосцицкий, В. Сикорский), так и личных противников И.В. Сталина. Например, в Глубокском районе Вилейской области на одном из бюллетеней красовалась надпись: «Да здравствует Леон Троцкий!» [11, л. 349].

По данным материалов по выборам, на избирательных бюллетенях были зафиксированы совершенно противоречивые надписи, в которых воздавалась хвала «государствам английскому и французскому» и одновременно гитлеровской Германии и лично А. Гитлеру. Известны случаи рисования на бюллете- нях нацистской свастики. В Мядельском районе Вилейской области, например, сохранилась такая надпись: «Германии вы дали 200 вагонов зерна, дерево даете, так как боитесь немцев, но они вас все равно погонят» [11, л. 345]. Это дает основания предположить, что у определенной части жителей Западной Белоруссии именно Советский Союз ассоциировался с главным агрессором, уничтожившим независимость Польши.

Таким образом, выборы в высшие органы государственной власти в Западной Белоруссии в 1940 г. проходили по тщательно разработанному сценарию с использованием немалых материальных и людских ресурсов. Достижению нужного, заранее спланированного результата способствовала хорошо отлаженная пропагандистская машина и силовые органы. Однако нельзя говорить о тотальной поддержке коммунистов со стороны жителей Западной Белоруссии, где были сильны пропольские и антисоветские настроения. Этот фактор власти вынуждены были учитывать в дальнейшей советизации региона.

\section{СПИСОК ЛИТЕРАТУРЫ}

1. Белозорович, В. А. Аграрные преобразования в западных областях Беларуси в 1939-1952 гг. : автореф. ... дис. канд. ист. наук / Белозорович Виктор Александрович. - Минск, 2000. - 20 с.

2. Великий, А. Ф. Архивы западных областей БССР в 1939-1941 гг. / А. Ф. Великий // Белорусский археографический ежегодник. - 2014. - Вып. 15. C. $75-82$.

3. Мисаревич, Е. А. На освобожденной земле. Политическая работа в западных областях Белоруссии (сентябрь 1939 - июнь 1941 гг.) / Е. А. Мисаревич. - Минск : Беларусь, 1989. - 96 с.

4. Национальный архив Республики Беларусь (далее-НАРБ). - Ф. 4. - Оп. 1. - Д. 13963.

5. НАРБ. - Ф. 4. - Оп. 1. - Д. 14593.

6. НАРБ. - Ф. 4. - Оп. 1. - Д. 14663.

7. НАРБ. - Ф. 4. - Оп. 1. - Д. 14571.

8. НАРБ. -Ф. 4. - Оп. 1. - Д. 15135.

9. НАРБ. - Ф. 4. - Оп. 1. - Д. 15326.

10. НАРБ. - Ф. 4. - Оп. 1. - Д. 15581.

11. НАРБ. - Ф. 4. - Оп. 1. - Д. 15584.

12. НАРБ. - Ф. 4. - Оп. 1. - Д. 16949.

13. НАРБ. - Ф. 4. - Оп. 1. - Д. 16752.

14. НАРБ. - Ф. 4. - Оп. 1. - Д. 16753.

15. НАРБ. - Ф. 4. - Оп. 1. - Д. 16760.

16. НАРБ. - Ф. 4. - Оп. 1. - Д. 16867. 
17. НАРБ. - Ф. 4. - Оп. 1. - Д. 16868.

18. НАРБ. - Ф. 4. - Оп. 1. - Д. 16793.

19. НАРБ. - Ф. 4. - Оп. 1. - Д. 17000.

20. Об утверждении «Положения о выборах в Верховный Совет Белорусской ССР» : постановление VIII сессии Центрального Исполнительного Комитета Белорусской ССР ХІ созыва, 27 февраля 1938 г. // Собрание законов и распоряжений Рабоче-крестьянского Правительства Белорусской Советской Социалистической Республики. - 1938. № 3. - Ст. 1 .

21. Павлов, И. Сергей Притыцкий / И. Павлов // Звезда. - 1940. - 27 февр. - С. 3.

22. Понуждаев, Д. Н. Советская рабоче-крестьянская милиция в устранении политической оппозиции на территории западных областей БССР в конце 1939 - первой половине 1941 г. / Д. Н. Понуждаев // Вестник Могилевского государственного университета им. А. Кулешова. Серия А «Гуманитарные науки». - 2013. - № 2. - С. 58-65.

23. Сноп, С. Н. Особенности организации и деятельности советской судебной власти на территории Западной Беларуси (1939-1956 гг.) : автореф. дис. ... канд. юрид. наук / Сноп Сергей Николаевич. - Гродно, 2002. -20 с.

24. Толочко, Д. М. Кадровая политика ЦК КП(б)Б в западных областях Беларуси (сентябрь 1939 - июнь 1941 гг.) / Д. М. Толочко // Научные труды Республиканского института высшей школы. Серия «Исторические и психологопедагогические науки». - 2011. - Вып. 11, ч. 1. C. 258-264.

25. Трацевская, Т. П. Социалистическое строительство в западных областях Белорусской ССР накануне Великой Отечественной войны (сентябрь 1939 - июнь 1941 г.) : автореф. ... дис. канд. ист. наук / Трацевская Тамара Павловна. - Минск, 1953. - 19 с.

26. Харченко, О. П. Культурные преобразования в западных областях Беларуси (сентябрь 1939 июнь 1941 гг.) / О. П. Харченко // Вестник Гродненского государственного университета. Серия 1 , История. Философия. Политология. Социология. 2009. - № 3. - С. 49-57.

27. Эмлимелах, 3. Организованно, по-большевистски проведем выборы / З. Эмлимелах, С. Ажгирей // Большевик Белоруссии. - 1940. - № 2. C. 27-34.

28. Трофімчик, А. В. Становлення радянської системи освіти в західних областях Білоруської Радянської Соціалістичної Республіки в 1939-1941 pp. : автореф. дис. ... канд. іст. наук / Трофімчик Анатолій Вікторович. - Київ, 2004. - 19 с.

29. Śleszcynski, W. Okupacja sowiecka na Bialostocczyznie w latach 1939-1941 / W. Śleszcynski. Bialystok : Agencja Wydawnicza Benkowski, 2001. $594 \mathrm{~s}$.

\section{REFERENCES}

1. Belozorovich V.A. Agrarnye preobrazovaniya v zapadnykh oblastyakh Belarusi v 1939-1952 gg.: avtoref. ... dis. kand. ist. nauk [Agrarian Transformations in the Western Areas of Belarus in 1939-1952. Cand. hist. sci. abs. diss.]. Minsk, 2000. 20 p.

2. VelikiyA.F. Arkhivy zapadnykh oblastey BSSR v 1939-1941 gg. [Archives of the BSSR Western Areas in 1939-1941]. Belorusskiy arkheograficheskiy ezhegodnik, 2014, iss. 15, pp. 75-82.

3. Misarevich E.A. Na osvobozhdennoy zemle. Politicheskaya rabota $v$ zapadnykh oblastyakh Belorussii (sentyabr 1939 - iyun 1941 g.) [On the Freed Land. Political Work in the Western Areas of Belarus (September 1939 - June 1941)]. Minsk, Belarus Publ., 1989. 96 p.

4. Natsionalnyy arkhiv Respubliki Belarus [National archive of Republic of Belarus], F. 4, Op. 1, D. 13963.

5. Natsionalnyy arkhiv Respubliki Belarus [National archive of Republic of Belarus], F. 4, Op. 1, D. 14593.

6. Natsionalnyy arkhiv Respubliki Belarus [National archive of Republic of Belarus], F. 4, Op. 1, D. 14663.

7. Natsionalnyy arkhiv Respubliki Belarus [National archive of Republic of Belarus], F. 4, Op. 1, D. 14571.

8. Natsionalnyy arkhiv Respubliki Belarus [National archive of Republic of Belarus], F. 4, Op. 1, D. 15135.

9. Natsionalnyy arkhiv Respubliki Belarus [National archive of Republic of Belarus], F. 4, Op. 1, D. 15326.

10. Natsionalnyy arkhiv Respubliki Belarus [National archive of Republic of Belarus], F. 4, Op. 1, D. 15581.

11. Natsionalnyy arkhiv Respubliki Belarus [National archive of Republic of Belarus], F. 4, Op. 1, D. 15584 .

12. Natsionalnyy arkhiv Respubliki Belarus [National archive of Republic of Belarus], F. 4, Op. 1, D. 16949.

13. Natsionalnyy arkhiv Respubliki Belarus [National archive of Republic of Belarus], F. 4, Op. 1, D. 16752.

14. Natsionalnyy arkhiv Respubliki Belarus [National archive of Republic of Belarus], F. 4, Op. 1, D. 16753.

15. Natsionalnyy arkhiv Respubliki Belarus [National archive of Republic of Belarus], F. 4, Op. 1, D. 16760 .

16. Natsionalnyy arkhiv Respubliki Belarus [National archive of Republic of Belarus], F. 4, Op. 1, D. 16867. 


\section{РЕГИОНОВЕДЕНИЕ}

17. Natsionalnyy arkhiv Respubliki Belarus [National archive of Republic of Belarus], F. 4, Op. 1, D. 16868

18. Natsionalnyy arkhiv Respubliki Belarus [National archive of Republic of Belarus], F. 4, Op. 1, D. 16793

19. Natsionalnyy arkhiv Respubliki Belarus [National archive of Republic of Belarus], F. 4, Op. 1, D. 17000 .

20. Ob utverzhdenii «Polozheniya o vyborakh v Verkhovnyy Sovet Belorusskoy SSR»: postanovlenie VIII sessii Tsentralnogo ispolnitelnogo komiteta Belorusskoy SSR XI sozyva, 27 fevralya 1938 g. [On Approving "The Provision on Elections to the Supreme Council of Belarusian Soviet Socialist Republic": Decree of the $8^{\text {th }}$ Session of the Central Executive Committee of Belarusian SSR of the $11^{\text {th }}$ Assembly, February 27, 1938]. Sobranie zakonov $i$ rasporyazheniy Raboche-krestyanskogo pravitelstva Belorusskoy Sovetskoy Sotsialisticheskoy Respubliki [Collected Laws and Regulations of the Workers' and Peasants' Government of the Belarus Soviet Socialist Republic], 1938, no. 3, art. 1.

21. Pavlov I. Sergey Pritytskiy [Sergey Pritytsky]. Zvezda, 1940, 27 February, p. 3.

22. Ponuzhdaev D.N. Sovetskaya rabochekrestyanskaya militsiya $\mathrm{v}$ ustranenii politicheskoy oppozitsii na territorii zapadnykh oblastey BSSR v kontse 1939 - pervoy polovine 1941 g. [The Soviet Workers' and Peasants' Militia in Elimination of Political Opposition in the Territory of the BSSR Western Areas at the End of 1939 - First Half of 1941]. Vestnik Mogilevskogo gosudarstvennogo universiteta im. A. Kuleshova. Seriya A «Gumanitarnye nauki», 2013, no. 2, pp. 58-65.

23. Snop S.N. Osobennosti organizatsii $i$ deyatelnosti sovetskoy sudebnoy vlasti na territorii Zapadnoy Belarusi (1939-1956 gg.): avtoref. dis. ... kand. yurid. nauk [Features of the Organization and Activity of the Soviet Judicial Authority in the Territory of the Western Belarus (1939-1956). Cand. jurid. sci. abs. diss.]. Grodno, 2002. 20 p.

24. Tolochko D.M. Kadrovaya politika TsK KP(b)B v zapadnykh oblastyakh Belarusi (sentyabr 1939 - iyun 1941 g.) [Personnel Policy of the Central Committee of CP(b)B in the Western Areas of Belarus (September 1939 - June 1941)]. Nauchnye trudy Respublikanskogo instituta vysshey shkoly. Seriya "Istoricheskie i psikhologo-pedagogicheskie nauki», 2011, iss. 11, part 1, pp. 258-264.

25. Tratsevskaya T.P. Sotsialisticheskoe stroitelstvo v zapadnykh oblastyakh Belorusskoy SSR nakanune Velikoy Otechestvennoy voyny (sentyabr 1939 - iyun 1941 g.): avtoref. ... dis. kand. ist. nauk [Socialist Construction in the Western Areas of Belarus Soviet Socialist Republic on the Eve of the Great Patriotic War (September 1939 - June 1941). Cand. hist. sci. abs. diss.]. Minsk, 1953. 19 p.

26. Kharchenko O.P. Kulturnye preobrazovaniya v zapadnykh oblastyakh Belarusi (sentyabr 1939 -iyun 1941 g.) [Cultural Transformations in the Western Areas of Belarus (September 1939 - June 1941)]. Vestnik Grodnenskogo gosudarstvennogo universiteta. Seriya 1, Istoriya. Filosofiya. Politologiya. Sotsiologiya, 2009, no. 3, pp. 49-57.

27. Emlimelakh Z., Azhgirey S. Organizovanno, po-bolshevistski provedem vybory [We Will Hold Elections Orderly, in a Bolshevist Way]. Bolshevik Belorussii, 1940, no. 2, pp. 27-34.

28. Trofimchik A.V. Stanovlennya radyanskoï sistemi osviti v zakhidnikh oblastyakh Biloruskoï Radyanskoï Sotsialistichnoï Respubliki v 19391941 r.: avtoref. dis. ... kand. ist. nauk [Formation of the Soviet Education System in the Western Areas of the Belarusian Soviet Socialist Republic in 1939-1941. Cand. hist. sci. abs. diss.]. Kiev, 2004. 19 p. (in Ukrainian).

29. Śleszcynski W. Okupacja sowiecka na Bialostocczyznie $w$ latach 1939-1941. Bialystok, Agencja Wydawnicza Benkowski, 2001. 594 p. (in Polish).

\section{Information about the Author}

Aleksandr V. Kuryanovich, Candidate of Sciences (History), Associate Professor, Employee of Institute of Political Research "Political Sphere", Fabienishkes St., 59-26, LT-07110 Vilnius, Republic of Lithuania, deklaration@mail.ru, http://orcid.org/0000-0003-2240-704X.

\section{Информация об авторе}

Александр Викторович Курьянович, кандидат исторических наук, доцент, сотрудник Института политических исследований «Политическая сфера», ул. Фабиёнишкес, 59-26, LT-07110 г. Вильнюс, Литовская Республика, deklaration@mail.ru, http://orcid.org/0000-0003-2240-704X. 